\title{
Angie Nishikihama
}

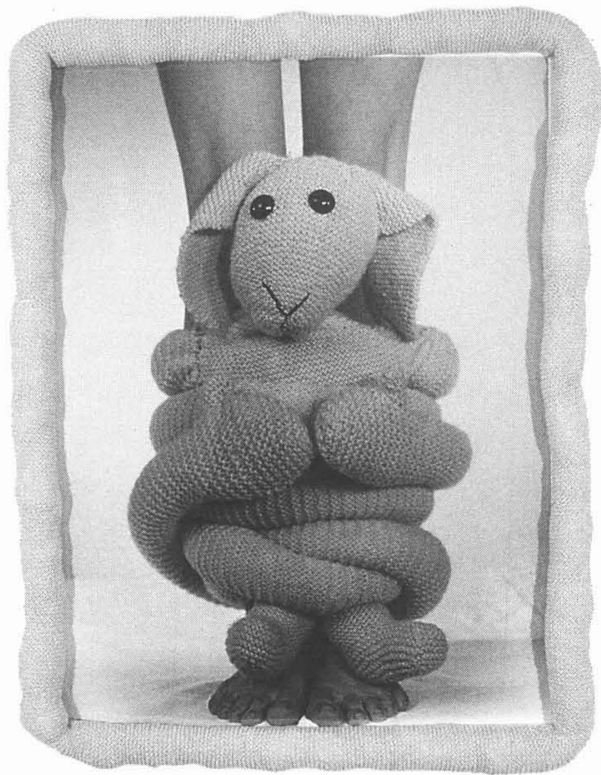

Arms Control, 2000, colour photograph with knit frame, $44 \times 34 \times 4^{\prime \prime}$

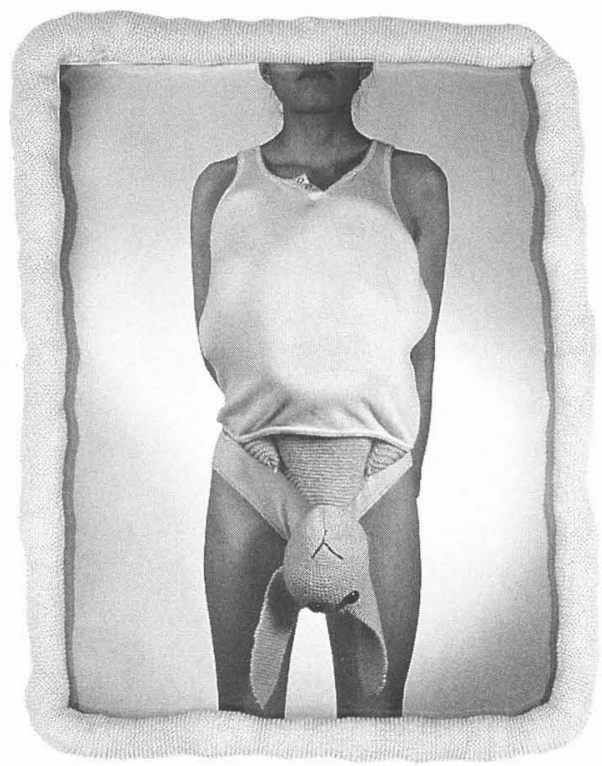

Independence Day, 2000, colour photograph with knit frame, $44 \times 34 \times 4^{\prime \prime}$ 


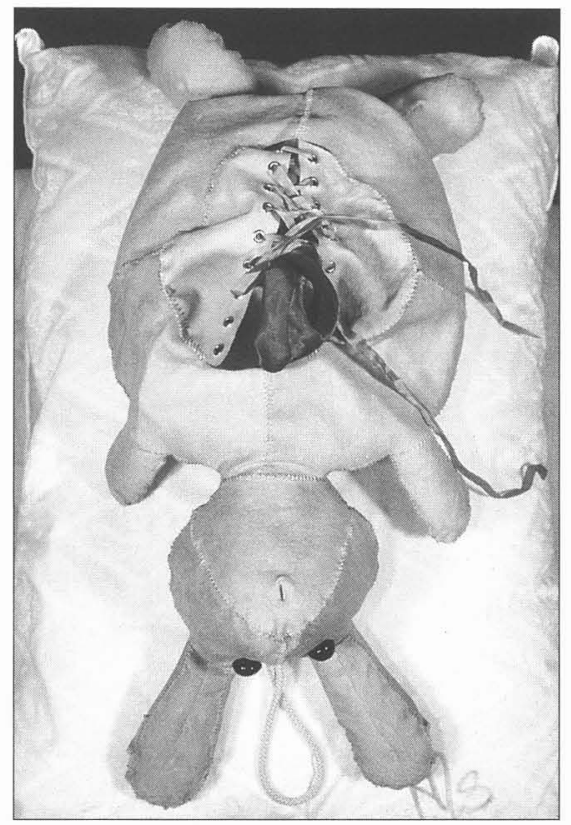

Untitled (close-up), 2001, latex, glass eyes, embroidery thread, eyelets, ribbon, stuffing, satin nightdresses, bedding, $31 \times 28 \times 28^{\prime \prime}$

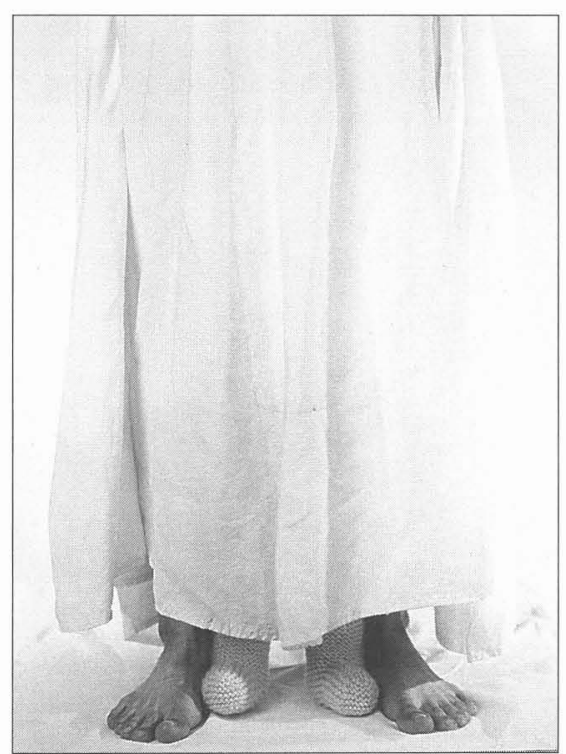

The Homecoming, 2000, colour photograph, $40 \times 30^{\prime \prime}$ 